\title{
PENGEMBANGAN MEDIA ARTICULATE STORYLINE PADA MATERI KLASIFIKASI MAKHLUK HIDUP KELAS X SMA
}

\author{
Sri Indasah ${ }^{1}$ \\ DevitaSulistiana ${ }^{2}$ \\ Mar'atus Sholihah ${ }^{3}$ \\ ${ }^{1,2,3)}$ Pendidikan Biologi Universitas Islam Balitar Blitar \\ E-mail: ${ }^{1}$ indasahsriin25@gmail.com, ${ }^{2}$ devitasulistiana17@gmail.com, \\ ${ }^{3}$ maratussholihah11292@gmail.com
}

\begin{abstract}
The study aimed to determine the feasibility and the response of teachers and students to Articulate storyline media on living creature classification material. This type of research is Research and Development $(R \& D)$ regarding the Borg and Gall development model which is limited to the seventh stage namely product revision. The data taken is data on the feasibility of validation results by experts and student and teacher response tests. The research instrument used a validation questionnaire and a response questionnaire. The data analysis technique used is quantitative descriptive analysis. The result showed that the assessment of material experts, media experts, linguists, and IT experts were 66,6\%, $85,23 \%, 96 \%$, and $85,64 \%$ respectively. The average assessment by experts was $83,38 \%$. The percentage of the teacher readability test assessment was $91,83 \%$ and the percentage of the student readability test results was $92,85 \%$. This value is included in the very feasible criteria. The percentage of teacher response test assessments was $84 \%$ and the percentage of student response test assessments was $84,82 \%$. This value is included in the very good criteria. The assessment shows that the media Articulate Storyline in the living creature classification material for class tenth developed is suitable for use as a learning media.
\end{abstract}

Kata kunci: Articulate Storyline, Borg and Gall, Klasifikasi Makhluk Hidup, Media Pembelajaran

\section{PENDAHULUAN}

Kesuksesan proses pembelajaran ditentukan oleh beberapa faktor diantaranya yaitu kepala sekolah, tenaga pendidik atau guru, siswa, sarana dan prasarana yang memadai, media pembelajaran, dan kurikulum (Amran, 2015). Kepala sekolah menjadi faktor penentu kesuksesan dalam pembelajaran di sekolah, karena kepala sekolah memiliki peran educator atau pemimpin, peran menejer, peran administrator, dan peran leader atau pemimpin. Kesuksesan guru dalam melaksanakan pembelajaran dapat dilihat dari beberapa aspek penilaian, seperti pelaksanaan tugas, perencanaan, pelaksanaan, dan penilaian pembelajaran. Siswa sebagai penentu kesuksesan pembelajaran dapat dilihat dari penilaian hasil belajar siswa atau prestasi (Calista,
2019). Sarana dan prasarana memiliki peran penting dalam menunjang kualitas pembelajaran siswa, seperti gedung sekolah, laboratorium komputer, laboratorium IPA, lapangan sekolah, dan perpustakaan. Media pembelajaran juga menjadi salah satu faktor penentu kesuksesan dalam pembelajaran. Media pembelajaran dapat mempermudah guru dalam menyampaikan materi dan siswa juga lebih mudah dalam memahami materi yang dipelajari (Miftah, 2013).

Peranan media dalam proses pembelajaran yaitu dapat memperjelas penyajian materi dan dapat mengatasi keterbatasan ruang, waktu, serta daya indra. Objek yang terlalu kecil dapat dibantu dengan proyektor mikro, film bingkai, atau gambar. Gerak yang terlalu lambat atau terlalu cepat dapat dibantu dengan timelapse atau high speed photography. Kejadian atau 
peristiwa pada masa lalu dapat ditampilkan kembali lewat gambar atau foto, rekaman film, video, dan film bingkai. Objek yang terlalu kompleks dapat disajikan dengan diagram. Konsep yang terlalu luas dapat divisualisasikan dengan bentuk film, gambar, dan lain-lain (Nurhiba, 2016).

Berdasarkan fakta di lapangan terkait media yang ada di tiga sekolah menengah atas di Blitar diketahui bahwa, media pembelajaran yang digunakan oleh sebagian besar guru kurang bervariasi dan belum semua berbasis informasi dan teknologi (IT). Media pembelajaran yang digunakan oleh sebagian besar guru biologi sekolah menengah atas (SMA) di Blitar masih terbatas pada lembar kerja siswa (LKS). Berdasarkan angket analisis siswa diketahui bahwa $85,18 \%$ guru biologi menggunakan lembar kerja siswa dan $14,81 \%$ menggunakan modul untuk menunjang proses pembelajaran. Media pembelajaran yang digunakan oleh bapak atau ibu guru ketika menyampaikan pembelajaran biologi di kelas adalah 45,12\% menggunakan LCD dan $54,88 \%$ menggunakan fasilitas pembelajaran kurang memadai karena cukup dengan lembar kerja siswa.

Adanya media pembelajaran yang kurang bervariasi menyebabkan 51,92\% dari 120 siswa menyatakan mata pelajaran biologi sulit dan $40,57 \%$ siswa menyatakan bahwa materi klasifikasi makhluk hidup adalah materi yang sulit, karena klasifikasi makhluk hidup cakupan materinya luas dan di dalamnya terdapat banyak istilah ilmiah yang masih asing bagi siswa. Hasil belajar siswa pada materi klasifikasi makhluk hidup $60 \%$ masih di bawah kriteria ketuntasan minimal. Guru biasanya menerangkan materi klasifikasi makhluk hidup dengan cara menjelaskan materi yang ada di lembar kerja siswa, tetapi siswa kurang antusias dalam mempelajari materi tersebut karena merasa bosan. Dampak lain dari media pembelajaran yang kurang bervariasi dan tidak interaktif dapat mempengaruhi minat belajar siswa, keaktifan siswa, dan hasil belajar yang rendah (Suhayah, 2013). Begitu juga dengan bahan ajar yang kurang atau hanya menggunakan lembar kerja siswa akan berpengaruh pula terhadap hasil belajar siswa. Berdasarkan hasil penelitian yang telah dilakukan oleh Erma (2017) mengungkapkan bahwa guru yang hanya menggunakan lembar kerja siswa dan buku cetak saja dapat berdampak terhadap hasil belajar siswa yang rendah.

Berdasarkan permasalahan tersebut, maka bapak dan ibu guru memerlukan media pembelajaran yang bervariasi dan berbasis IT. Media pembelajaran berbasis IT dapat merangsang keaktifan siswa, mempermudah guru dalam menyampaikan materi yang diajarkannya, dapat menciptakan pembelajaran yang menyenangkan, dan fleksibel (Muslih, 2016). Salah satunya yaitu media Articulate Storyline. Media pembelajaran Articulate Storyline merupakan salah satu media pembelajaran yang komprehensif karena di dalam satu aplikasi terdapat gambar yang disertai dengan tulisan, kuis, dan video. Karakter siswa saat ini adalah digital native karena saat ini merupakan revolusi industri 4.0, sehingga siswa lebih senang belajar dengan menggunakan media pembelajaran berbasis IT. Media pembelajaran IT dapat memberikan apa yang diharapkan siswa yaitu situasi belajar yang menyenangkan sehingga siswa lebih ingat terhadap materi yang dipelajari (Suhayah, 2013). Media pembelajaran Articulate Storyline merupakan media yang dapat menarik perhatian siswa dan bisa menstimulus siswa untuk belajar dengan perasaan senang dan penuh antusias (Wahyuni, 2015). Media Articulate Storyline merupakan salah satu media yang cocok digunakan dalam pembelajaran materi klasifikasi mahluk hidup karena Articulate Storyline merupakan sebuah perangkat lunak yang dapat digunakan untuk membuat presentasi yang komprehensif dan kreatif. Articulate Storyline memiliki beberapa kelebihan antara lain yaitu terdapat tutorial yang dapat dipublish secara online maupun ofline, di dalam satu aplikasi terdapat banyak menu, aplikasi ini mudah diakses dan ditransfer melalui HP android, dan siswa dapat 
mengerjakan soal latihan melalui kuis serta dapat mengetahui hasilnya secara langsung sehingga memungkinkan siswa dapat belajar secara mandiri (Wahyuni, 2015).

Pengembangan media Articulate Storyline pernah dilakukan oleh beberapa peneliti diantaranya oleh Ropi'i (2017) yang berjudul Pengembangan Media Pembelajaran Digital History Timeline Berbasis Articulate Storyline 2 Materi Proklamasi Kemerdekaan Indonesia untuk Kelas XI SMKN 1 Udanawu Kabupaten Blitar. Berdasarkan uji coba yang dilakukan, media pembelajaran Digital History Timeline Materi Proklamasi Kemerdekaan Indonesia merupakan media pembelajaran yang layak. Penelitian yang lain juga dilakukan oleh Yasin, dkk (2017) tentang Kelayakan Teoritis Multimedia Interaktif Berbasis Articulate Storyline Materi Sistem Reproduksi Manusia Kelas XI SMA. Pada penelitian tersebut dinyatakan bahwa media yang dikembangkan sudah layak dan sesuai. Pengembangan serupa dilakukan oleh Fitriani (2015) di MTs Sunan Kali Jaga Malang yang berjudul Pengembangan Media Ajar Berbasis Multimedia Articulate Storyline Sejarah Kebudayaan Islam materi Khulafaur Rasyidin Kelas VII Madrasah Tsanawiyah Sunan Kalijaga Malang menunjukkan bahwa media tersebut efektif digunakan dalam pembelajaran Sejarah Kebudayaan Islam.

Berdasarkan fakta yang telah diungkapkan, dapat diketahui bahwa media yang disertai gambar yang menarik, video, dan suara dapat dikemas dalam bentuk media Articulate Storyline sehingga dapat menumbuhkan ketertarikan siswa dalam mempelajari materi biologi dan harapannya dapat meningkatkan hasil belajar siswa. Berdasarkan latar belakang yang telah diuraikan perlu dilakukan penelitian dengan judul "Pengembangan Media Articulate Storyline pada Materi Klasifikasi Makhluk Hidup Kelas X SMA".

Tujuan penelitian ini adalah (1) untuk mengetahui kelayakan produk media Articulte Storyline pada materi klasifikasi makhluk hidup; (2) untuk mengetahui respon guru dan siswa terhadap produk media Articulte Storyline pada materi klasifikasi makhluk hidup.

\section{METODE}

Penelitian ini menggunakan pendekatan deskriptif kuantitatif. Jenis penelitian yang digunakan adalah Penelitian dan Pengembangan (Research and Development). Desain serta model penelitian dan pengembangan dalam penelitian ini megacu pada desain pengembangan Borg and Gall. Menurut Borg dan Gall langkahlangkah pelaksanaan penelitian dan pengembangan adalah sebagai berikut: (1) penelitian dan pengumpulan informasi awal; (2) perencanaan; (3) pengembangan format produk awal; (4) uji coba awal; (5) revisi produk; (6) uji coba lapangan; (7) revisi produk; (8) uji pelaksanaan; (9) revisi produk akhir; (10) desiminasi dan implementasi (Arifin, 2012).

Langkah-langkah desain dan pengembangan pada penelitian ini dibatasi sampai tahap ketujuh, yaitu sebagai berikut.

1) Tahap Penelitian dan Pengumpulan Informasi

Tujuan dari tahap pengumpulan informasi ini adalah untuk memperoleh data sehingga peneliti dapat mengetahui kebutuhan siswa akan pembelajaran di lapangan. Dalam tahap pengumpulan data ini peneliti menggunakan cara studi lapangan dan studi pustaka. Peneliti menggunakan studi lapangan dengan tujuan untuk memperoleh informasi terkait kurikulum pembelajaran di sekolah, karakter siswa, media pembelajaran yang digunakan bapak/ibu guru, situasi pembelajaran yang dibutuhkan siswa, dan sumber belajar yang ada di sekolah, Sedangkan studi pustaka dilakukan peneliti dengan tujuan untuk mengetahui karakteristik media pembelajaran Articulate Storyline dan untuk mengetahui cakupan materi klasifikasi mahluk hidup untuk SMA.

2) Tahap Perencanaan

Tahap perencanaan yaitu menyusun rencana penelitian, tahap 
perencanaan ini meliputi rumusan tujuan pembelajaran yang hendak dicapai, desain produk, langkah-langkah dalam penelitian, pengujian produk dalam lingkup terbatas, pembenahan, dan pengujian produk dalam lingkup yang lebih luas.

3) Tahap Pengembangan Format Produk Awal

Tahap pengembangan format produk awal ini dimulai dengan pengumpulan materi klasifikasi mahluk hidup, kemudian materi yang sudah terkumpul, jenis kuis, dan video ditampilkan dalam aplikasi Articulate Storyline. Selanjutnya dilakukan validasi ahli materi, ahli media, ahli Bahasa, dan ahli IT.

4) Tahap Uji Coba Awal

Uji coba awal (uji keterbacaan) dilakukan pada satu sekolah dengan melibatkan subjek uji coba tiga guru biologi dan enam siswa kelas X MIA SMA/MA. Selama uji coba, dilakukan pengamatan/observasi terhadap kegiatan guru dengan menggunakan produk Articulate Storyline tersebut. Setelah dilakukan uji coba, maka peneliti dapat memberikan angket keterbacaan pada guru terkait produk yang peneliti kembangkan.

Uji coba oleh enam siswa dilakukan dengan cara menyampaikan media Articulate Storyline disertai pemberian angket keterbacaan kepada siswa yang telah disediakan peneliti yang terdiri atas 11 pernyataan sebagai bentuk tanggapan dari siswa mengenai media Articulate Storyline.

5) Tahap Revisi Produk Setelah Uji Coba Awal

Setelah dilakukan uji coba tahap awal, maka dapat diketahui kelemahan atau kekurangan dari produk yang dikembangkan berdasarkan angket keterbacaan. Produk direvisi sesuai penilaian data kualitatif yang telah diperoleh sebelum akhirnya diujicobakan ke kelompok yang lebih luas sehingga diperoleh hasil kelayakan dari media
Articulate Storyline dalam pembelajaran biologi pada materi klasifikasi makhluk hidup.

6) Tahap Uji Coba Lapangan

Uji coba lapangan (uji coba produk lebih luas) merupakan tahap penting pada penelitan dan pengembangan yang dilakukan pada Sekolah Menengah Atas (SMA/MA). Uji coba yang lebih luas ini dilakukan pada 26 siswa MAN 2 Blitar kelas X MIA. Uji coba lapangan memiliki tujuan untuk mengetahui respon guru dan siswa terhadap media Articulate Storyline pada materi klasifikasi makhluk hidup. Selanjutnya, pada uji coba ini masingmasing responden diberikan angket respon guru dan siswa.

7) Tahap Revisi Produk Setelah Uji Coba Lapangan

Setelah dilakukan uji coba lapangan, maka diperoleh data berupa hasil uji respon siswa dan guru yang peneliti gunakan untuk mengetahui respon siswa dan guru dari produk yang dikembangkan, sehingga dapat diketahui pula hasil kelayakan dari media Articulate Storyline dalam pembelajaran biologi pada materi klasifikasi makhluk hidup.

\section{HASIL}

\section{Analisis Potensi Masalah dan Solusi}

Berdasarkan hasil observasi potensi masalah pada pembelajaran biologi di tiga sekolah menengah atas di Blitar diketahui bahwa $54,88 \%$ media belajar kurang bervariasi, $51,92 \%$ dari 120 siswa menyatakan bahwa biologi merupakan mata pelajaran yang sulit, dan $40,57 \%$ siswa menyatakan bahwa klasifikasi makhluk hidup adalah materi yang sulit, karena klasifikasi makhluk hidup cakupan materinya luas dan di dalamnya terdapat istilah ilmiah yang masih asing bagi siswa. Hasil belajar siswa pada materi klasifikasi makhluk hidup $60 \%$ masih di bawah kriteria ketuntasan minimal (KKM). Guru biasanya menerangkan materi klasifikasi makhluk 
hidup dengan cara menjelaskan materi yang ada di lembar kerja siswa (LKS).

Dampak adanya kendala dalam pembelajaran bagi guru dan siswa yaitu siswa kesulitan dalam memahami materi klasifikasi makhluk hidup. Siswa merasa bosan dan tidak antusias dalam belajar biologi sehingga hasil belajar siswa rendah.

Solusi untuk mengatasi kendala tersebut yaitu guru memerlukan media pembelajaran yang bervariasi dan dapat menarik perhatian siswa. Siswa mampu memahami materi klasifikasi makhluk hidup dengan mudah dan dengan perasaan senang jika menggunakan media pembelajaran yang bervariasi. Salah satu media pembelajaran yang bervariasi dan menarik yaitu media berupa gambar yang dipadukan dengan tulisan dan video, salah satunya yaitu media pembelajaran Articulate Storyline pada materi klasifikasi makhluk hidup.

Keunggulan media Articulate Storyline yaitu terdapat tutorial yang dapat dipublish secara online maupun ofline. Di dalam satu aplikasi terdapat banyak menu, aplikasi ini mudah diakses dan ditransfer melalui HP android. Siswa dapat mengerjakan soal latihan melalui kuis serta dapat mengetahui hasilnya secara langsung sehingga memungkinkan siswa dapat belajar secara mandiri.

Desain Awal Produk dan Pengembangan

Desain awal produk dilakukan dengan membuat rancangan media dengan melakukan persiapan sebagai berikut. (1) penyusunan garis besar isi media; (2) Jabaran materi; (3) Story board; (4) Naskah media. Tampilan produk jadi Articulate Storyline dapat dilihat pada Tabel 1.

Tabel 1 Tampilan produk articulate storyline

\begin{tabular}{|c|c|c|}
\hline No & Tampilan & Keterangan \\
\hline 1 & & $\begin{array}{l}\text { Halaman } \\
\text { utama } \\
\text { Di dalamnya } \\
\text { berisi tentang } \\
\text { profil } \\
\text { pengembang, } \\
\text { KD dan tujuan, }\end{array}$ \\
\hline
\end{tabular}

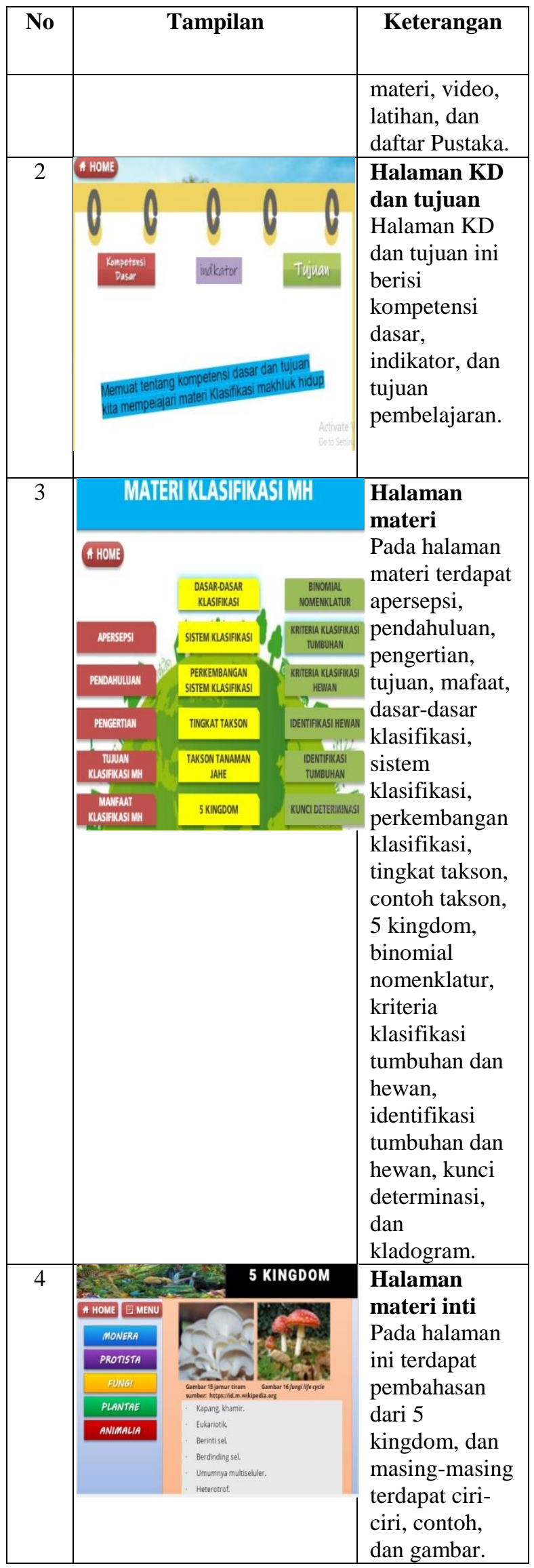




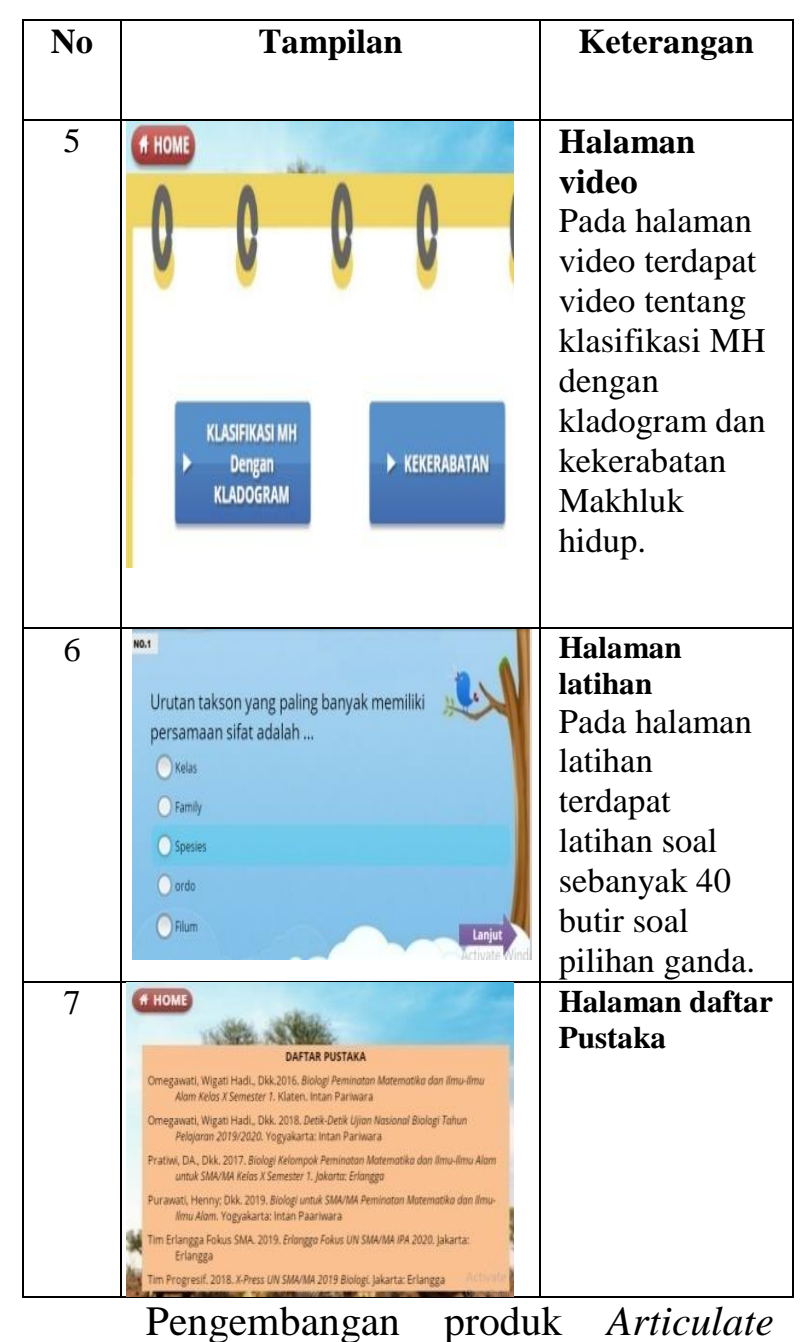

Storyline dilakukan dengan tiga tahap, yaitu sebagai berikut.

\section{Pra produksi}

Pada tahap ini peneliti mempersiapkan alat dan bahan seperti laptop/komputer, pengeras suara, untuk kebutuhan video dan audio, jabaran materi, serta naskah. Sedangkan perangkat lunak (software) untuk mendukung pengembangan media yaitu KineMaster untuk membuat video kekerabatan mahluk hidup serta video kladogram, dan Articulate Storyline untuk mengembangkan media pembelajaran interaktif.

\section{Produksi}

Langkah pertama adalah pembuatan menu utama/halaman utama media pembelajaran. Langkah kedua adalah membuat menu petunjuk dengan tujuan agar media pembelajaran lebih terarah dan mudah digunakan. Langkah ketiga adalah pembuatan menu materi yaitu dengan menambahkan teks yang diperlukan pada menu materi serta menambahkan video klasifikasi makhluk hidup dengan kladogram dan video kekerabatan makhluk hidup. Langkah keempat yaitu menambahkan kuis melalui menu latihan yang ada dalam Articulate Storyline.

3. Pasca produksi

Produk media pembelajaran klasifikasi mahluk hidup terlebih dahulu diperiksa apakah media tersebut masih ada kesalahan dan kekurangan. Pemeriksaan dimulai dari kelengkapan materi, kesempurnaan animasi, audio dan video, serta ketepatan tombol navigasi yang terdapat pada media pembelajaran klasifikasi makhluk hidup. Setelah proses pemeriksaan selesai, media dipublish supaya dapat dibaca dan digunakan pada laptop atau komputer yang tidak terinstal software Articulate Storyline. Selanjutnya media pembelajaran klasifikasi mahluk hidup divalidasi oleh tiga ahli materi, tiga ahli media, tiga ahli bahasa, dan tiga ahli IT.

\section{Hasil Pengembangan Produk}

Prototipe yang telah selesai dikembangkan selanjutnya divalidasi oleh beberapa ahli yaitu ahli materi, media, bahasa, dan IT. Hasil validasi prototipe dari beberapa ahli tersebut dijabarkan sebagai berikut.

Ahli materi yang menjadi validator dalam penelitian ini adalah dua dosen program studi pendidikan biologi dan satu guru biologi dengan jenjang pendidikan S2 dan memiliki kompetensi dengan pokok bahasan dalam media yang dikembangkan, yaitu materi klasifikasi mahluk hidup. Hasil penilaian kelayakan aspek kesesuaian isi materi dan penyajian dapat dilihat pada Tabel 2. 
Tabel 2 Hasil penilaian media articulate storyline oleh ahli materi

\begin{tabular}{|c|c|c|c|c|c|c|}
\hline \multirow[t]{2}{*}{ No } & \multirow{2}{*}{$\begin{array}{c}\text { Kriteria } \\
\text { penilaian }\end{array}$} & \multirow{2}{*}{$\begin{array}{c}\text { Butir } \\
\text { ke }\end{array}$} & \multicolumn{3}{|c|}{ Penilaian } & \multirow[t]{2}{*}{ Jumlah skor } \\
\hline & & & Ahli 1 & Ahli 2 & Ahli 3 & \\
\hline \multirow{4}{*}{ A } & \multirow{4}{*}{ Isi materi } & 1 & 4 & 3 & 3 & 10 \\
\hline & & 2 & 4 & 4 & 4 & 12 \\
\hline & & 3 & 3 & 4 & 3 & 10 \\
\hline & & 4 & 3 & 3 & 3 & 9 \\
\hline \multirow{3}{*}{ B } & \multirow{3}{*}{ Penyajian } & 5 & 4 & 4 & 2 & 10 \\
\hline & & 6 & 3 & 3 & 3 & 9 \\
\hline & & 7 & 3 & 3 & 4 & 10 \\
\hline \multicolumn{2}{|c|}{ Jumlah skor } & & 24 & 24 & 22 & 70 \\
\hline \multicolumn{2}{|c|}{ Skor kriterium } & & & & & 105 \\
\hline \multicolumn{3}{|c|}{ Persentase } & & & & $66,67 \%$ \\
\hline
\end{tabular}

Tabel 3 Hasil penilaian articulate storyline oleh ahli media

\begin{tabular}{|c|c|c|c|c|c|c|}
\hline \multirow[b]{2}{*}{ No } & \multirow[b]{2}{*}{ Kriteria penilaian } & \multirow[b]{2}{*}{ Butir ke } & \multicolumn{3}{|c|}{ Penilaian } & \multirow[t]{2}{*}{ Jumlah skor } \\
\hline & & & Ahli 1 & Ahli 2 & Ahli 3 & \\
\hline \multirow[t]{2}{*}{$\mathrm{A}$} & \multirow[t]{2}{*}{ Huruf yang digunakan } & 1 & 4 & 4 & 4 & 12 \\
\hline & & 2 & 4 & 4 & 4 & 12 \\
\hline \multirow[t]{4}{*}{$\mathrm{B}$} & \multirow{4}{*}{$\begin{array}{l}\text { Kejelasan } \\
\text { gambar dan tata letak } \\
\text { gambar }\end{array}$} & 3 & 5 & 4 & 4 & 13 \\
\hline & & 4 & 4 & 4 & 5 & 13 \\
\hline & & 5 & 5 & 4 & 4 & 13 \\
\hline & & 6 & 4 & 4 & 5 & 13 \\
\hline \multirow[t]{3}{*}{$\mathrm{C}$} & \multirow[t]{3}{*}{ Penyusunan bagian isi } & 7 & 5 & 4 & 5 & 14 \\
\hline & & 8 & 5 & 4 & 4 & 13 \\
\hline & & 9 & 5 & 4 & 4 & 13 \\
\hline \multirow[t]{3}{*}{$\mathrm{D}$} & \multirow[t]{3}{*}{ Pengoperasian } & 10 & 5 & 4 & 5 & 14 \\
\hline & & 11 & 3 & 4 & 4 & 11 \\
\hline & & 12 & 4 & 4 & 5 & 13 \\
\hline \multirow[t]{2}{*}{$\mathrm{E}$} & \multirow{2}{*}{ Kegunaan } & 13 & 4 & 4 & 5 & 13 \\
\hline & & 14 & 4 & 4 & 4 & 12 \\
\hline \multicolumn{3}{|c|}{ Jumlah skor } & 61 & 56 & 62 & 179 \\
\hline \multicolumn{3}{|c|}{ Skor kriterium } & & & & 210 \\
\hline \multicolumn{3}{|c|}{ Persentase } & & & & $85,23 \%$ \\
\hline
\end{tabular}

Tabel 4 Hasil penilaian articulate storyline oleh ahli bahasa

\begin{tabular}{|c|c|c|c|c|c|c|}
\hline \multirow[b]{2}{*}{ No } & \multirow{2}{*}{$\begin{array}{c}\text { Kriteria } \\
\text { penilaian }\end{array}$} & \multirow[t]{2}{*}{ Butir ke } & \multicolumn{3}{|c|}{ Penilaian } & \multirow{2}{*}{$\begin{array}{c}\text { Jumlah } \\
\text { skor }\end{array}$} \\
\hline & & & Ahli 1 & Ahli 2 & Ahli 3 & \\
\hline \multirow{5}{*}{ A } & \multirow{5}{*}{ Aspek bahasa } & 1 & 5 & 5 & 5 & 15 \\
\hline & & 2 & 5 & 4 & 4 & 13 \\
\hline & & 3 & 5 & 5 & 4 & 14 \\
\hline & & 4 & 5 & 5 & 5 & 15 \\
\hline & & 5 & 5 & 5 & 5 & 15 \\
\hline \multicolumn{2}{|c|}{ Jumlah skor } & & 25 & 24 & 23 & 72 \\
\hline \multicolumn{3}{|c|}{ Skor kriterium } & & & & 75 \\
\hline \multicolumn{3}{|c|}{ Persentase } & & & & $96 \%$ \\
\hline
\end{tabular}

Tabel 5 Hasil penilaian articulate storyline oleh ahli IT

\begin{tabular}{|c|c|c|c|c|c|c|}
\hline \multirow[b]{2}{*}{ No } & \multirow{2}{*}{$\begin{array}{c}\text { Kriteria } \\
\text { penilaian }\end{array}$} & \multirow{2}{*}{$\begin{array}{c}\text { Butir } \\
\text { ke }\end{array}$} & \multicolumn{3}{|c|}{ Penilaian } & \multirow{2}{*}{$\begin{array}{c}\text { Jumlah } \\
\text { skor }\end{array}$} \\
\hline & & & Ahli 1 & Ahli 2 & Ahli 3 & \\
\hline \multirow[t]{6}{*}{ A } & Kualitas & 1 & 4 & 5 & 5 & 14 \\
\hline & tampilan & 2 & 4 & 5 & 4 & 13 \\
\hline & & 3 & 4 & 5 & 4 & 13 \\
\hline & & 4 & 4 & 5 & 4 & 13 \\
\hline & & 5 & 5 & 5 & 4 & 14 \\
\hline & & 6 & 5 & 4 & 4 & 13 \\
\hline
\end{tabular}


S. INDAHSAH, D. SULISTIANA, \& M. SHOLIHAH, PENGEMBANGAN....

\begin{tabular}{|c|c|c|c|c|c|c|}
\hline \multirow[t]{2}{*}{ B } & \multirow{2}{*}{$\begin{array}{l}\text { Rekayasa } \\
\text { perangkat lunak }\end{array}$} & 7 & 4 & 5 & 4 & 13 \\
\hline & & 8 & 4 & 5 & 5 & 14 \\
\hline \multirow[t]{2}{*}{$\mathrm{C}$} & \multirow[t]{2}{*}{ Keterlaksanaan } & 9 & 4 & 5 & 4 & 13 \\
\hline & & 10 & 3 & 5 & 4 & 12 \\
\hline \multirow[t]{2}{*}{ D } & \multirow[t]{2}{*}{ Tampilan visual } & 11 & 4 & 4 & 4 & 12 \\
\hline & & 12 & 4 & 4 & 3 & 11 \\
\hline E & Perawatan & 13 & 3 & 5 & 4 & 12 \\
\hline \multicolumn{2}{|c|}{ Jumlah skor } & & 52 & 62 & 53 & 167 \\
\hline \multicolumn{2}{|c|}{ Skor kriterium } & & & & & 195 \\
\hline \multicolumn{2}{|c|}{ Persentase } & & & & & $85,64 \%$ \\
\hline
\end{tabular}

Tabel 6 Rekapitulasi hasil penilaian media articulate storyline

\begin{tabular}{lllll}
\hline No & \multicolumn{1}{c}{ Validator } & \multicolumn{1}{c}{ Komponen } & Persentase (\%) & \multicolumn{1}{c}{ Kriteria } \\
\hline A & Ahli materi & Kelayakanisi/materi & $66,67 \%$ & Layak \\
\hline B & Ahli media & Penyajian & $85,23 \%$ & Sangat layak \\
\hline C & Ahli bahasa & Bahasa & $96 \%$ & Sangat layak \\
\hline D & Ahli IT & Perangkat lunak & $85,64 \%$ & Sangat layak \\
\hline & & Rata-rata & $83,38 \%$ & Sangat layak \\
\hline
\end{tabular}

Tabel 7 Hasil penilaian uji keterbacaan media articulate storyline oleh guru

\begin{tabular}{|c|c|c|c|c|c|c|}
\hline \multirow[t]{2}{*}{ No } & \multirow[t]{2}{*}{ Kriteria Penilaian } & \multirow{2}{*}{$\begin{array}{c}\text { Butir } \\
\text { soal ke }\end{array}$} & \multicolumn{3}{|c|}{ Penilaian } & \multirow[t]{2}{*}{ Jumlah } \\
\hline & & & Guru ke-1 & Guru ke-2 & Guru ke- 3 & \\
\hline \multirow[t]{3}{*}{ A } & \multirow[t]{3}{*}{ Aspek Bahasa } & 1 & 4 & 5 & 4 & 13 \\
\hline & & 2 & 5 & 5 & 4 & 14 \\
\hline & & 3 & 5 & 5 & 4 & 14 \\
\hline \multirow[t]{5}{*}{ B } & \multirow[t]{5}{*}{ Isi Materi } & 4 & 5 & 5 & 4 & 14 \\
\hline & & 5 & 5 & 5 & 4 & 14 \\
\hline & & 6 & 4 & 5 & 4 & 13 \\
\hline & & 7 & 5 & 5 & 4 & 14 \\
\hline & & 8 & 5 & 5 & 4 & 14 \\
\hline \multirow[t]{5}{*}{$\mathrm{C}$} & \multirow[t]{5}{*}{ Penyajian } & 9 & 4 & 5 & 4 & 13 \\
\hline & & 10 & 5 & 5 & 5 & 15 \\
\hline & & 11 & 4 & 5 & 5 & 14 \\
\hline & & 12 & 4 & 5 & 4 & 13 \\
\hline & & 13 & 5 & 4 & 4 & 13 \\
\hline \multirow{2}{*}{$\mathrm{D}$} & \multirow{2}{*}{$\begin{array}{c}\text { Penggunaan } \\
\text { Huruf }\end{array}$} & 14 & 5 & 5 & 4 & 14 \\
\hline & & 15 & 5 & 5 & 4 & 14 \\
\hline \multirow[t]{4}{*}{$\mathrm{E}$} & \multirow{4}{*}{$\begin{array}{c}\text { Kejelasan } \\
\text { Pemilihan dan } \\
\text { Tata Letak } \\
\text { Gambar }\end{array}$} & 16 & 5 & 5 & 5 & 15 \\
\hline & & 17 & 4 & 5 & 5 & 14 \\
\hline & & 18 & 5 & 5 & 4 & 14 \\
\hline & & 19 & 5 & 5 & 5 & 15 \\
\hline \multirow[t]{3}{*}{$\mathrm{F}$} & \multirow{3}{*}{$\begin{array}{c}\text { Penyusunan } \\
\text { Bagian Isi }\end{array}$} & 20 & 3 & 5 & 4 & 12 \\
\hline & & 21 & 4 & 5 & 4 & 13 \\
\hline & & 22 & 5 & 5 & 4 & 14 \\
\hline \multicolumn{2}{|c|}{ Jumlah skor } & & 101 & 109 & 93 & 303 \\
\hline \multicolumn{3}{|c|}{ Skor kriterium } & & & & 330 \\
\hline \multicolumn{3}{|c|}{ Persentase (\%) } & & & & $91,81 \%$ \\
\hline
\end{tabular}

Tabel 8 Hasil penilaian uji keterbacaan siswa pada media Articulate Storyline

\begin{tabular}{|c|c|c|c|c|c|c|c|c|c|}
\hline \multirow[b]{2}{*}{ No } & \multirow[t]{2}{*}{ Kriteria Penilaian } & \multirow{2}{*}{$\begin{array}{l}\text { Butir } \\
\text { ke }\end{array}$} & \multicolumn{6}{|c|}{ Penilaian } & \multirow[t]{2}{*}{$\sum$ skor } \\
\hline & & & $\begin{array}{l}\text { Siswa } \\
\text { ke-1 }\end{array}$ & $\begin{array}{l}\text { Siswa } \\
\text { ke-2 }\end{array}$ & $\begin{array}{l}\text { Siswa } \\
\text { ke-3 }\end{array}$ & $\begin{array}{l}\text { Siswa } \\
\text { ke-4 }\end{array}$ & $\begin{array}{c}\text { Siswa } \\
\text { ke-5 }\end{array}$ & $\begin{array}{c}\text { Siswa } \\
\text { ke-6 }\end{array}$ & \\
\hline \multirow[t]{5}{*}{$\mathrm{A}$} & Cakupan Materi & 1 & 5 & 5 & 4 & 5 & 5 & 5 & 29 \\
\hline & & 2 & 5 & 4 & 4 & 5 & 4 & 4 & 26 \\
\hline & & 3 & 4 & 5 & 5 & 5 & 4 & 5 & 28 \\
\hline & & 4 & 5 & 5 & 5 & 5 & 5 & 5 & 30 \\
\hline & & 5 & 5 & 4 & 5 & 5 & 4 & 4 & 27 \\
\hline
\end{tabular}


S. INDAHSAH, D. SULISTIANA, \& M. SHOLIHAH, PENGEMBANGAN....

\begin{tabular}{|c|c|c|c|c|c|c|c|c|c|}
\hline \multirow[b]{2}{*}{ No } & \multirow[t]{2}{*}{ Kriteria Penilaian } & \multirow{2}{*}{$\begin{array}{l}\text { Butir } \\
\text { ke }\end{array}$} & \multicolumn{6}{|c|}{ Penilaian } & \multirow[t]{2}{*}{$\sum$ skor } \\
\hline & & & $\begin{array}{l}\text { Siswa } \\
\text { ke-1 }\end{array}$ & $\begin{array}{l}\text { Siswa } \\
\text { ke-2 }\end{array}$ & $\begin{array}{l}\text { Siswa } \\
\text { ke-3 }\end{array}$ & $\begin{array}{l}\text { Siswa } \\
\text { ke-4 }\end{array}$ & $\begin{array}{l}\text { Siswa } \\
\text { ke-5 }\end{array}$ & $\begin{array}{l}\text { Siswa } \\
\text { ke-6 }\end{array}$ & \\
\hline \multirow[t]{2}{*}{$\mathrm{B}$} & \multirow[t]{2}{*}{ Aspek Bahasa } & 6 & 5 & 4 & 5 & 5 & 5 & 5 & 29 \\
\hline & & 7 & 4 & 5 & 5 & 5 & 5 & 4 & 28 \\
\hline \multirow[t]{5}{*}{$\mathrm{C}$} & \multirow[t]{5}{*}{ Tampilan } & 8 & 5 & 5 & 5 & 5 & 4 & 5 & 29 \\
\hline & & 9 & 4 & 4 & 4 & 5 & 5 & 5 & 27 \\
\hline & & 10 & 4 & 5 & 5 & 5 & 4 & 4 & 27 \\
\hline & & 11 & 5 & 4 & 5 & 5 & 4 & 5 & 28 \\
\hline & & 12 & 4 & 4 & 5 & 5 & 4 & 5 & 27 \\
\hline \multirow[t]{2}{*}{$\mathrm{D}$} & \multirow[t]{2}{*}{ Keterlaksanaan } & 13 & 5 & 4 & 4 & 5 & 4 & 5 & 27 \\
\hline & & 14 & 4 & 5 & 5 & 5 & 4 & 5 & 28 \\
\hline \multicolumn{3}{|c|}{ Jumlahskor } & 76 & 63 & 66 & 70 & 61 & 66 & 390 \\
\hline \multicolumn{3}{|c|}{ Skor kriterium } & & & & & & & 420 \\
\hline \multicolumn{3}{|c|}{ Persentase $(\%)$} & & & & & & & $92,85 \%$ \\
\hline
\end{tabular}

Tabel 9 Hasil penilaian uji respon guru pada media articulate storyline

\begin{tabular}{|c|c|c|c|c|c|c|}
\hline \multirow[t]{2}{*}{ No } & \multirow[t]{2}{*}{ Kriteria Penilaian } & \multirow[t]{2}{*}{ Butir ke- } & \multicolumn{3}{|c|}{ Penilaian } & \multirow{2}{*}{$\begin{array}{c}\text { Jumlah } \\
\text { skor }\end{array}$} \\
\hline & & & $\begin{array}{l}\text { Guru } \\
\text { ke-1 }\end{array}$ & $\begin{array}{l}\text { Guru } \\
\text { ke-2 }\end{array}$ & $\begin{array}{l}\text { Guru } \\
\text { ke-3 }\end{array}$ & \\
\hline \multirow[t]{15}{*}{ A } & \multirow[t]{15}{*}{ Respon pada Media } & 1 & 4 & 4 & 5 & 13 \\
\hline & & 2 & 5 & 4 & 5 & 14 \\
\hline & & 3 & 3 & 3 & 5 & 11 \\
\hline & & 4 & 3 & 5 & 5 & 13 \\
\hline & & 5 & 4 & 4 & 5 & 13 \\
\hline & & 6 & 4 & 4 & 5 & 13 \\
\hline & & 7 & 3 & 3 & 5 & 11 \\
\hline & & 8 & 4 & 4 & 5 & 13 \\
\hline & & 9 & 4 & 3 & 5 & 12 \\
\hline & & 10 & 4 & 3 & 5 & 12 \\
\hline & & 11 & 5 & 5 & 5 & 15 \\
\hline & & 12 & 5 & 5 & 4 & 14 \\
\hline & & 13 & 4 & 3 & 2 & 9 \\
\hline & & 14 & 4 & 4 & 5 & 13 \\
\hline & & 15 & 4 & 4 & 5 & 13 \\
\hline Jumlal & & & 60 & 58 & 71 & 189 \\
\hline Skor k & & & & & & 225 \\
\hline Persen & & & & & & $84 \%$ \\
\hline
\end{tabular}

Hasil penilaian uji respon dari dua puluh enam siswa memperoleh persentase sebesar $84,82 \%$. Nilai ini termasuk dalam rentang $80 \%<x \leq 100 \%$ dalam kriteria penskoran, dan termasuk dalam kriteria sangat baik. Media Articulate Storyline pada materi klasifikasi makhluk hidup ditinjau dari respon siswa dinyatakan sangat baik.

\section{PEMBAHASAN}

Pengembangan media Articulate Storyline pada materi klasifikasi makhluk hidup bertujuan untuk mengetahui kelayakan media Articulate Storyline berdasarkan validasi para ahli, validasi praktisi, dan respon dari subjek uji coba.
Berdasarkan hasil validasi dari para ahli media Articulate Storyline pada materi klasifikasi makhluk hidup dinyatakan sangat layak dengan perolehan skor $\geq 80 \%$ dengan kriteria sangat layak.

1. Tingkat Kelayakan Media Articulate Storyline

Tingkat kelayakan media Articulate Storyline dapat dilihat dari penilaian ahli materi, ahli media, ahli bahasa, ahli IT, guru biologi, dan siswa. Komponen kelayakan isi atau materi dinilai oleh ahli materi memperoleh persentase rata-rata sebesar $66,67 \%$ dan termasuk kriteria layak. Pembuatan media pembalajaran harus memperhatikan pesan yang disampaikan 
sehingga mengurangi verbalistis, mengatasi perbatasan ruang, waktu, tenaga, serta daya indera, meningkatkan motivasi belajar, dan melihat aspek interaksi antara siswa dengan sumber belajar sehingga siswa mampu belajar mandiri sesuai dengan bakat dan gaya belajarnya (Daryanto, 2016). Cakupan materi pada Articulate Storyline sudah sesuai dengan kompetensi inti dan kompetensi dasar pada materi klasifikasi makhluk hidup. Uraian materi sudah sesuai dengan konsep klasifikasi makhluk hidup, tujuan dan manfaat klasifikasi, mengidentifikasi tingkatan takson dalam klasifikasi, binomial nomenklatur, kunci determinasi dan kladogram.

Beberapa alasan media Articulate Storyline mendapat nilai tinggi dari validator ahli materi yaitu penyajian isi atau materi mudah dipahami oleh siswa dan penggunaan ilustrasi gambar sudah sesuai uraian materi serta disertai sumber gambar. Media gambar dapat meningkatkan aktivitas belajar siswa pada pembelajaran IPA kelas III materi bumi dan cuaca dengan mencapai indikator aktif dalam indikator aktivitas belajar (Embun, 2015). Usaha guru dalam menggunakan media gambar dapat meningkatkan hasil belajar siswa, sehingga siswa lebih tertarik untuk belajar dan lebih memahami materi pembelajaran (Rohini, 2010). Gambar atau foto dalam media pembelajaran dapat menarik perhatian siswa dan dapat meningkatkan minat belajar siswa. Pada umumnya siswa sudah mampu menangkap pesan dalam gambar tersebut, sehingga siswa lebih menguasai apa yang disampaikan oleh guru melalui gambar dibanding dengan tulisan saja (Irfan, 2017). Beberapa alasan yang membuat media ini tidak mendapat skor maksimum saat validasi karena ada beberapa materi yang pembahasannya kurang seperi taksonomi hewan dan kunci dikotom, dan identitas gambar belum diberi nomor. Namun demikian kekurangan ini sudah diperbaiki saat dilakukan revisi produk, sehingga saat uji coba produk materi pada media Articulate Storyline sudah lengkap dan sesuai dengan kompetensi dasar.

Komponen penyajian yang dinilai oleh ahli media memperoleh persentase $85,23 \%$ dan termasuk dalam kriteria sangat layak. Media ini di dalamnya terdapat video kladogram dan kekerabatan makhluk hidup yang menarik, sehingga media ini memperoleh nilai tinggi. Penggunaan video dalam media interaktif mampu menjelaskan keadaan real dari suatu proses dan kejadian atau fenomena. Pengguna juga bisa mengulang pada bagian-bagian tertentu untuk mencermati gambaran agar lebih fokus (Munir, 2013). Video dapat merangsang motivasi belajar siswa, video pembelajaran dapat meningkatkan proses dan hasil belajar siswa, siwa juga dapat melakukan lebih banyak kegiatan belajar, karena siswa tidak hanya mendengarkan uraian guru tetapi juga melakukan aktivitas lain seperti mengamati dan mendemonstrasikan (Nugroho, 2015). Komposisi antara huruf yang digunakan, kejelasan pemilihan gambar, tata letak gambar, dan penyusunan bagian isi sudah sangat baik. Media Articulate Storyline dapat dioperasikan dengan mudah serta dapat digunakan sewaktu-waktu dan berulang-ulang. Media ini tidak memerlukan perawatan khusus dan dapat mendukung proses pembelajaran. Keunggulan lainnya dari media Articulate Storyline yaitu kemasan produk yang menarik. Kemasan dapat menarik perhatian, meningkatkan daya tarik, dan merangsang persepsi konsumen tentang produk. Kemasan produk juga menyampaikan nilai khas suatu produk (Vishnu, 2014). Beberapa alasan yang menyebabkan media Articulate Storyline tidak mendapatkan nilai maksimum dari ahli media adalah audio yang terdapat pada video kladogram masih lemah.

Komponen aspek bahasa yang dinilai oleh ahli bahasa memperoleh persentase $96 \%$ dan termasuk dalam kriteria sangat layak. Istilah dalam media 
Articulate Storyline menggunakan bahasa baku dan penggunaan bahasa dapat memudahkan siswa dalam memahami materi klasifikasi makhluk hidup yang harus dikuasai siswa. Keberhasilan dalam proses pembelajaran dipengaruhi oleh penggunaan bahasa yang tepat. Siswa akan mudah memahami apa yang akan disampaikan oleh guru jika guru menggunakan media pembelajaran dengan bahasa dan penulisan yang tepat. Proses pembelajaran dan bahasa tidak dapat dipisahkan antara satu dengan lainnya, karena satu komponen akan mempengaruhi komponen yang lain (Sari, 2015). Alasan yang menyebabkan media Articulate Storyline tidak mendapat skor maksimum dari ahli bahasa adalah ada beberapa ejaan penulisan yang masih salah dan ada beberapa kalimat yang tidak diakhiri dengan tanda titik.

Komponen rekayasa perangkat lunak yang dinilai oleh ahli IT memperoleh persentase $85,64 \%$. Nilai tersebut termasuk dalam kriteria sangat layak. berdasarkan penilaian ahli IT aspek kualitas tampilan, rekayasa perangkat lunak, keterlaksanaan, tampilan visual, dan perawatan sudah sangat baik. Multimedia interaktif dilengkapi dengan controller yang dapat dioperasikan oleh pengguna atau siswa, sehingga akan menimbulkan hubungan timbal balik antara siswa dengan media. Kelebihan multimedia yaitu dapat memberikan umpan balik langsung kepada siswa. Siswa dapat menentukan beberapa pilihan seperti melihat video atau mengerjakan latihan soal yang dilengkapi kunci jawaban. Dengan demikian siswa dapat belajar mandiri dengan berlatih mengerjakan latihan soal dan bisa memeriksa jawabannya serta mengetahui nilainya secara langsung (Ampa, 2015). Beberapa alasan yang menyebabkan media Articulate Storyline tidak memperoleh skor maksimum dari ahli IT adalah gradasi warna antara teks, gambar, dan background terlalu tajam dan perlu diperhalus agar tidak mengganggu penglihatan.

Penilaian produk oleh guru biologi bertujuan untuk mengetahui kelayakan media Articulate Storyline sebagai media pembelajaran. Perolehan persentase penilaian guru biologi sebesar 91,81\% dan termasuk dalam kriteria sangat layak. Berdasarkan penilaian guru biologi aspek bahasa, isi materi, aspek penyajian, penggunaan huruf, kejelasan pemilihan dan tata letak gambar, serta penyusunan bagian isi sudah sangat baik. Media Articulate Storyline ini memperoleh skor maksimum karena terdapat buku petunjuk yang disertai gambar yang menarik. Penggunaan buku bergambar yang menarik dapat meningkatkan motivasi belajar siswa (Emosda, 2017). Keunggulan media Articulate Storyline yang lain yaitu di dalam media pembelajaran terdapat kuis. Kuis berbasis android dapat meningkatkan hasil belajar siswa (Rohmatin, 2020). Berdasarkan saran guru biologi perlu ditambah gambar lagi agar media lebih menarik.

Subjek uji coba lapangan awal adalah enam siswa MAN 2 Blitar kelas X MIA 4. Uji coba produk lapangan awal bertujuan untuk mengetahui keterbacaan media yang telah dikembangkan. Perolehan persentase penilaian angket keterbacaan sebesar $92,85 \%$ dan nilai tersebut termasuk dalam kriteria sangat layak. Berdasarkan penilaian angket keterbacaan aspek cakupan materi, aspek bahasa, tampilan, dan keterlaksanaan sudah sangat baik. Meskipun media sudah termasuk dalam kriteria sangat layak, kritik dan saran siswa perlu dipertimbangkan. Menurut siswa media ini masih ada beberapa yang perlu diperbaiki, seperti tampilan setiap halaman perlu dibuat lebih menarik lagi sehingga dapat menambah daya tarik siswa untuk membaca.

2. Tingkat Respon Guru dan Siswa terhadap Media Articulate Storyline 
Tingkat respon guru dan siswa terhadap media Articulate Storyline dapat dilihat dari penilaian uji respon guru dan siswa. Penilaian uji respon guru memperoleh persentase sebesar $84 \%$. Nilai ini termasuk dalam rentang $80 \%<\mathrm{x} \leq 100 \%$ dalam kriteria penskoran dan termasuk dalam kriteria sangat baik. Media ini memperoleh nilai tinggi karena desain pada cover buku menarik. Desain cover buku yang menarik dapat menangkap daya tarik pembaca. Cover dapat menangkap perhatian pembaca terhadap buku dan juga memberikan stimulus, sehingga pembaca tertarik pada buku tersebut. Jika pembaca sudah tertarik memungkinkan adanya keputusan untuk membaca dan mempelajarinya (Saputra, 2015). Meskipun media pembelajaran Articulate Storyline sudah sangat baik, kritik dan saran guru masih perlu dipertimbangkan. Menurut guru media pembelajaran Articulate Storyline ini masih ada beberapa yang perlu diperbaiki seperti perlu ditambah animasi agar lebih menarik lagi.

$$
\text { Penilaian respon siswa }
$$

memperoleh persentase sebesar $84,82 \%$. Nilai ini termasuk dalam rentang $80 \%<\mathrm{x} \leq 100 \%$ dalam kriteria penskoran, dan termasuk dalam kriteria sangat baik. Media ini memperoleh respon sangat baik karena di dalam media terdapat gambargambar yang menarik dan mendukung materi klasifikasi makhluk hidup. Gambar dalam media pembelajaran dapat menarik perhatian siswa dan dapat meningkatkan minat belajar siswa. Penggunaan media bergambar dapat membuat siswa aktif dalam kegiatan pembelajaran, siswa lebih bersemangat, dan tidak mengeluh pada saat proses belajar mengajar di kelas (Akbar, 2018). Meskipun media pembelajaran Articulate Storyline sudah sangat baik, tetapi kritik dan saran siswa tetap perlu dipertimbangkan. Menurut siswa media pembelajaran Articulate Storyline ini masih ada beberapa yang perlu diperbaiki, seperti perlu ditambah animasi agar lebih menarik lagi.

\section{KESIMPULAN}

Berdasarkan analisis data yang telah dilakukan, dapat disimpulkan sebagai berikut: (1) kelayakan media Articulate Storyline berdasarkan penilaian ahli materi, ahli media, ahli bahasa, dan ahli IT berturutturut adalah sebesar $66,67 \%, 85,23 \%, 96 \%$, dan $85,64 \%$. Nilai rata-rata ahli sebesar $83,38 \%$ dengan kriteria sangat layak. Persentase penilaian uji keterbacaan guru sebesar $91,81 \%$ dan persentase penilaian uji keterbacaan siswa sebesar $92,85 \%$ dengan kriteria sangat layak. Nilai ini menunjukkan bahwa media Articulate Storyline pada materi klasifikasi makhluk hidup yang dikembangkan layak digunakan sebagai media pembelajaran; (2) respon guru terhadap media Articulate Storyline memperoleh persentase sebesar $84 \%$, sedangkan respon siswa terhadap media Articulate Storyline memperoleh persentase sebesar $84,82 \%$ dengan kriteria sangat baik.

\section{SARAN}

Berdasarkan kesimpulan di atas, peneliti dapat memberikan saran terkait dengan masalah yang berhubungan dengan pengembangan. Adapun saran tersebut adalah sebagai berikut: (1) peneliti diharapkan dapat mengembangkan media pembelajaran Articulate Storyline untuk materi selain klasifikasi makhluk hidup; (2) penelitian Borg and Gall yang dilakukan hanya sampai tahap ketujuh yaitu revisi produk setelah uji respon, oleh karena itu peneliti menyarankan peneliti lain untuk menyempurnakan ke tahap penelitian dan pengembangan.

\section{DAFTAR RUJUKAN}

Akbar, A. A, Tarman. 2018. Gambar terhadap Hasil Belajar Bahasa Indonesia pada Siswa Kelas IV Sekolah Dasar. JPRD Jurnal Riset Pendidikan Dasar, 1(1): 40-48. www.reserchgate.net>publication 
Ampa, A.T. 2015. The Implementation of Interactive Multimedia Learning Materials in Teaching Listening Skill. English Language Teaching, 8(12): 56-62. files.eric.ed.gov $>$ fulltextpdf

Alam, S. 2019. Guru, Kurikulum, dan Pendidikan Bermutu. Online. bhinekanusantara.id. Diakses pada 28 November 2020

Arifin, Z. 2012. Penelitian Pendidikan Metode dan Paradigma Baru. Bandung: Remaja Rosdakarya

Calista, E.H. 2019. Faktor-Faktor yang Mempengaruhi Keberhasilan Belajar Siswa. Online. Kompasiana.com/eudorahanacalista/ 5dafccfco97f36104e4c7bc2/factoryang-mempengaruhi-keberhasilanbelajar-pada-siswa?page $=2$. Diakses pada 28 November 2020

Daryanto. 2016. Media Pembelajaran . Yogyakarta: Gava Media

Embun, S, Astuti, M. 2015. Pengaruh Penggunaan Media Gambar terhadap Aktivitas Hasil Belajar Siswa pada Mata Pelajaran IPA Materi Bumi dan Cuaca di Madrasah Ibtidaiyah Palembang. Jurnal Raden Fatah. (1): 81-107.

Emosda. 2017. Pengaruh Penggunaan Buku Cerita Bergambar terhadap Motivasi Belajar pada Siswa Sekolah Dasar. Jurnal Gentala Pendidikan Dasar, 2(2):256-274.

Irfan. 2017. Pengaruh Penggunaan Media Gambar terhadap Kemampuan Bercerita dalam Bahasa Bugis Siswa Kelas VIII SMP Negeri 4 Sinjai Timur. Skripsi. Fakultas Bahasa dan Sastra. Universitas Negeri Makassar. Makassar

Miftah, M. 2013. Fungsi dan Peran Media Pembelajaran Sebagai Upaya Peningkatan Kemampuan Belajar Siswa. Jurnal Kwangsan, 1(2): 93105.

Munir. 2013. Multimedia: Konsep dan Aplikasinya dalam Pendidikan. Bandung: Alfabeta
Muslih. 2016. Pemanfaatan Media Pembelajaran Berbasis ICT pada Lembaga Pendidikan Non-Formal $T P Q$.

Online. www.researchgate.net>publication. Diakses pada 13 Januari 2021

Nugroho, T.A.T. 2015. Pengaruh Penggunaan Media Video Pembelajaran terhadap Keterampilan Proses IPA dan Hasil Belajar IPA pada Siswa Kelas V SD Rejowinangun 1 Yogyakarta Tahun Ajaran 2014/2015. Skripsi. Fakultas Ilmu Pendidikan. Universitas Negeri Yogyakarta. Yogyakarta

Nurhiba. 2016. Peranan Media dalam Pembelajaran. Online. www.kompasiana.com. Diakses pada 28 November 2020

Rohini. 2010. Pengaruh Penggunaan Media Gambar terhadap Hasil Belajar Ilmu Pengetahuan Sosial Siswa Kelas IV SDN 02 Korleko. Jurnal Education, 5(2):75-90.

Rohmatin, A.Q.N. 2020. Pengaruh Game Kuis Berbasis Android terhadap Hasil Belajar Siswa pada Mata Pelajaran Fiqih Kelas VIII di MTs Nurul Huda Sedati Sidoarjo. Skripsi. Fakultas Tarbiyah dan Keguruan. Universitas Islam Negeri Sunan Ampel. Surabaya

Ropi'i, I. 2017. Pengembangan Media Digital History Time Line berbasis Articulate Story line 2. Online. http://karya-ilmiah.um.ac.id. Diakses pada 29 Januari 2019

Saputra, A.S, Wibowo, Aryanto. 2015. Pengaruh Desain Cover Novel Bertemakan Percintaan Terhadap Daya Tarik Audience di Surabaya. Online. Publication.petra.ac.id.pdf. Diakses pada 2 November 2020

Sari, S.D.P. 2015. Manfaat Media PembelajaranBerbasis ICT (Information and Comunication Technology) dalamPembelajaran Bahasa Indonesia. Online. www.researchgate.net>publication.p df. Diakses pada 3 November 2020 
Suhayah, Y. 2013. Pengaruh Penggunaan Media Interaktif Terhadap Hasil Belajar dan Sikap Cinta Tanah Air Peserta Didik. Education Journal, 1(2): 75-87.

Wahyuni, T. 2015. Efektivitas Penggunaan Media Audiovisual pada Pembelajaran Energi dalamSistem Kehidupan pada Siswa SMP. Unnes Science Education Journal,4(3):9981004. 